\title{
Orthodox Christianity contrasted with Buddhism: A brief reflection and comparative analysis
}

\author{
Rev. Dr. Razvan Tatu \\ Romanian Orthodox Church \\ Greek Orthodox Archbishopric of Johannesburg and Pretoria \\ Patriarchate of Alexandria and All Africa \\ South Africa \\ Rev. Prof. Dr. Angelo Nicolaides \\ Department of Philosophy and Applied Ethics \\ Faculty of Arts, University of Zululand, KwaDlangezwa, \\ South Africa \\ http//:orcid.org/0000-0002-2153-2853
}

DOI: https://doi.org/10.46222/pharosjot.10213

\begin{abstract}
There are diverse living religions in the world, and they exist as they likely meet various needs including the spiritual as well as material, of the people who espouse them. The religions require a systematic study as one looks at their teachings and the religious life they embrace. This article proffers an investigation on the theme of Christianity juxtaposed with Buddhism. It especially looks at themes including the role of religion, ethics, spirituality, prayer, grace, God, considerations of peace, salvation, good and evil and the afterlife. It is evident that there are indeed similarities and overlapping issues but there are equally many differences between these two great global religions. The article concludes that distinctive character of the religions can only be ascertained through an analysis of the fundamental concepts such as those considered in this article.
\end{abstract}

Keywords: Buddhism, Orthodoxy, faith, ethics, peace, justice, salvation.

\section{Concepts unpacked}

Buddhism is a path of religious practice and spiritual development leading to insight into the true nature of reality and it seeks conscious human enlightenment. Buddhism also refers to religious groups whose ultimate human objective is nirvana and whose path to nirvana emanates from the teachings of Buddha (Corduan, 1998)

Christianity is an Abrahamic monotheistic religion based on the life and teachings of Jesus of Nazareth. It identifies Jesus as the Saviour of humanity from sin and death through His death and Glorious resurrection (Hopfe \& Woodward, 2005)

\section{Introduction}

Religion is the foundation for morals and beliefs that one embraces, and it moulds its followers to determine what is considered to be either wrong or right in terms of interaction with others and the natural environment. We should respect the beliefs of all even if we disagree with them. The spiritual truths vary from faith to faith and the perspectives of others need to be considered. There are growing numbers of unaffiliated believers and they are becoming far more materialistic, at least on some important issues emanating from religious belief. Many people affiliated with a particular religious tradition believe that religion is very important in their lives and in their belief in an afterlife and Creator God or universal spirit. To arrive at an 
understanding of the spirit that lies inside a religion and in order to make meaningful comparisons, we need to ask questions about human salvation and the doctrine of man, because the nature of salvation and its accomplishment is dependent on the condition of man in his world and in relation to the divine (Bloom, 1956).

Christians generally argue that there are absolute standards for right and wrong, but there are large differences within Christianity. Among members of non-Christian faiths, such as Buddhism, about three-quarters assert that determining right from wrong is often situational (Pew Research Center, 2015). When looking for answers to questions about right and wrong, more people are likely to say they turn to practical experience and common sense than to any other source of guidance but religious beliefs and teachings, and also philosophy and reason or scientific information are also important (Pew Research Center, 2015).

The origin of the spiritual and religious quest are the essential questions that concern ideas such as human origin, the environment, how things came to be as they are, and what happens to one in the afterlife. Christianity and Buddhism as the study areas in this short research work have diverse ways of thinking on a range of issues and thus offer miscellaneous ideas about the role of religion, ethics, spirituality, prayer, grace, God, considerations of peace, justice, salvation, good and evil and the afterlife.

Because religion is a highly abstract theme, it is imperative to reconnoitre it so as to have a broader understanding of where two of the main religions, namely Christianity and Buddhism, stand on issues of faith. Each has its own often unique moral way of envisioning how the world works and people need to be knowledgeable about what their experiences of life really are in terms of their selected faith. The paradigms of a religion can be compared with those of any another faith. Christianity and Buddhism per se, each deliver their own set of ideals, ethics and standards to their adherents and astonishingly, various moral ways of rationalising a wide range of subjects are analogous. There are seemingly many differences such as for example Christians have faith in God, whereas Buddhists have no god. The Buddha showed people the way, while Jesus Christ stated that he was 'the way'. (International.la-croix.com, 2014). Christianity promises believers eternal life in the Kingdom of God while for a Buddhist, highest state is that of enlightenment, and freedom from being reborn. There are also various similarities for example, the spirit of compassion, bodhicitta in Sanskrit, is as dominant in Buddhism just as that of agape love is to Christianity. Both pray and believe in saintly figures. In Christianity there are saints, who demonstrate faith for the followers. Tibetan and Chinese Buddhism has saintlike figures, Bodhisattvas (for example, in Chinese 观音菩萨, Guānyīn púsà, figuratively meaning kind-hearted or compassionate person), whose examples altruistically illuminate the way called the dharma (International.la-croix.com, 2014).

\section{Towards a Methodology}

In any scientific approach to religion one must do justice to the circumstances and selfunderstanding of the believer. To that extent that a researcher conceives himself to be a Christian or a Buddhist, constitutes his ultimate frame of reference. In this brief study, a comparative approach was applied whose primary goal was to describe and offer a better understanding of a particular historical-empirical item by means of comparison. Comparing Orthodox Christianity with Buddhism, can serve a heuristic resolve by categorizing aspects and facets that might otherwise be greatly ignored. The researchers' produced insights by defamiliarizing the familiar, since Buddhism and Christianity are both traditions with a consciously preserved, past and future slanted ancient dimension. Thus both faiths have a robust interest in their individual prospects moving forward. Comparison is very fundamental to our cognition so that thinking about diverse faiths without comparison is virtually absurd. In this view cultural 
relativism is important to consider since the rationality of the conjecture of much that is measured to be scientific in the West is being increasingly questioned, including faith and especially Christianity. It is clear that diverse persons see the world in different terms and what they consider to be truth is highly dependent on dissimilar perspectives. A limitation of this study has been its brevity as only a couple of very elementary issues were considered for discussion while many other important aspects relating to the religions in questions have been omitted.

\section{Defining Religion}

Religion is generally understood to be a social-cultural system of chosen behaviours and practices, observances, morals and ethics, worldviews, scriptures, hallowed places, prophecies, or organizations, that relate humanity to supernatural, transcendental, and spiritual fundamentals (Merriam-Webster 2019). There is however no strict accord over what precisely constitutes a religion (Morreall \& Sonn, 2013; Nongbri, 2013). Yinger (1970) argues that religion is invariably "a system of beliefs and practices by means of which a group of people struggle with the ultimate problems of human life".

In Christianity, the Greek word thriskeia, (religion) was accepted by Greek writers such as Herodotus and Josephus, and it is also found in the New Testament (Brent, 2013). For Buddhists, the Sanskrit word dharma, occasionally translated as religion, means law (Social Sci LibreTexts, 2021), and it includes actually three vital aspects of Buddhist religiosity, that is the three refuges (triratna): the Buddha (the Enlightened one), dharma (his teachings) and samgha (the monastic community). Dissimilar religions may or may not comprise several fundamentals fluctuating from the divine aspects (James, 1902), to sacred and holy things or things "set apart and forbidden - beliefs and practices which unite into one single moral community called a Church, all those who adhere to them" (Durkheim, 1915), then to faith issues (Tillich, 1957) and also supernatural entities (Vergote, 1996). Toynbee, articulates that religion is: "the presence in the world of something spiritually greater than man himself" (Crawford, 2002).

The moral values of religious belief systems serve as a guide to the adherents of religions as the articulate how people should live their lives. Thus, knowledge of what is "right" or "wrong" is very important in faith propagation. Buddhism and Christianity were instituted by spiritually enlightened entities who offer different paths to human salvation and emphasise different approaches to human spirituality and other aspects of faith. Jesus and Buddha both enjoyed an lofty and divine standing in the communities which developed around them.

\section{The basics - Buddhism}

Buddhism is a "way of life" or a "spiritual tradition" which focusses on the life and teachings of Siddhartha Gautama ( $5^{\text {th }}-4^{\text {th }}$ century BCE), who is known as the Buddha or the 'enlightened one', or 'one who is awake'. Buddhism was founded more than 2,500 years ago in India and has approximately 470 million adherents, with the largest community of adherents in China at present. For a Buddhist, the path to enlightenment is achieved by applying morality, meditation and wisdom (de Bary, 1969). Buddhists believe they need to meditate regularly since because it helps rouse truth (Laumakis, 2008). Gautama was born into a wealthy aristocratic family of the Shakya clan in what is today the country of Nepal. He was greatly moved by the suffering he saw in the world around him and opted to give up his lavish lifestyle and endure poverty. He endorsed the idea of the "Middle Way," which means existing between two extremes and he therefore sought after a life deprived of social indulgences but also without total deficiency (Bodhi, 2005; Gethin, 1998). It took him six years to become enlightened while meditating under a Bodhi tree and he then spent the remainder of his life teaching others how to achieve 
a desired spiritual state. Vesak day is the day in which the birth, the awakening, and the parinirvana of the Buddha is celebrated which commemorates Buddha's birth, enlightenment and ultimately death. In addition, during each quarter of the moon, Buddhists partake in a ritual called Uposatha. Which permits them to renew their obligation to adhere to their teachings. Buddhism is a religion of redemption no matter which branch one adheres to, Hinayana or Mahayana.

\begin{abstract}
Buddha attempted many forms of asceticism, but found that none of them would bring release from rebirth because they sapped the strength of the body and the mind, which, as he saw, were important in the attaining release. Gautama realized that to cure sickness one must know its cause the cause one must have a clear mind. A clear mind requires a nourished body. $\mathrm{He}$ embarked on the middle path between licentiousness and extreme mortification. Buddha's enlightenment consisted of an insight into the nature of life and the method for gaining re- lease from it. ... He had an understanding of life and a method for dealing with it. We see something of Buddha's attitude to human life from the path he laid out. His emphasis on desire and suffering tends to place existence in the shadow as evil. (Bloom, 1956: 272).
\end{abstract}

In Udana VII-4. the human predicament is clearly desire and estrangement from life, pushing humanity into further suffering due to egoism (Rhys Davids, 1928). Thus Buddha encouraged his supporters to be zealous, "... rather, I beseech you, Ananda, in your own behalf. Devote yourselves to your own good...". Thus Buddhist practicality stresses that one should use time to the best advantage in securing a release (Burtt, 1955; Bloom, 1956). Buddha's teachings were based on his perception of dukkha (suffering) and the end of dukkha-the state called Nirvana. He is the 'Enlightened One' who has transcended Karma and escaped the ongoing cycle of birth and rebirth (Thompson, 2020). Buddhism is essentially a nontheistic religion or philosophical approach to life and it does not have faith in in a supreme creator God, this making it a more anthropocentric system (Nakamura, 1964). Buddhism is a breakaway part of Hinduism and is a Dharmic religion (Hirakawa, 1990; Keown \& Prebish, 2013). Contemplation and mindfulness are at the core of the Buddhist faith which stresses personal effort as a route to nirvana (Von Hinüber, 1997; Pratt, 1951).

Rebirth is one of the key beliefs of Buddhists and the philosophical objective is to eradicate mental anguish. They believe that people are in an interminable cycle of birth, death and rebirth, which can only be broken by achieving nirvana. Attaining thereof is the solitary way to escape misery in an enduring way (Thompson, 2020). Buddha insisted he was a mere human and asserted that there is no omnipotent compassionate or personal God. The notion of an omniscient, omnipotent, omnipresent God is thus totally excluded by Buddhists (Strong, 2001). People are by nature uninformed and mere emotional beings until they experience truth. In Buddhist texts, once Buddha was awakened he was asked whether he was a normal human being, and he replied, "No". Buddhism stresses the following aspects for life: Meditation, observing what is termed the Eightfold Path, having a right view, right ambition, right speech, right action, right livelihood, right exertion, right mindfulness, and right concentration (Kalupahana, 1994; Strong, 2001). Buddhism accentuates the endless cycle of birth and rebirth and the idea of reincarnation (samsara) is fully accepted and the notion of iniquity is not a Buddhist concept. Buddhists accept that every person has to work hard for their personal liberation and this may in fact take several lifetimes and immense discipline. A person seeking nirvana has to experience it for themselves through a transformation of human nature and a calmness of mind (Folwer, 2005; Pratt, 1951).

The Buddhist Sangha (Sanskrit for monasteries), are composed of male bhikkhus (monks) and female bhikkhunis (nuns). The Sangha is supported by lay Buddhists. Monks and nuns do not marry and remain celibate. Advice is offered in the discourses on how to maintain a contented and harmonious marriage for adherents. The Sangha have and continue to ardently 
keep a range of Buddhist texts safe over many centuries and they interpret and teach the communities Buddhist philosophy. They additionally follow strict discipline and teach the Dharma (Religious Law) to Buddhist adherents (Gombrich, 1988; Strong, 2001; Fowler, 2005). Statues are used in Buddhist temples and also shrines, as tools to meditation and they are venerated since they imitate the qualities of the Buddha who is considered to be the founder and chief teacher of Buddhism. $\mathrm{He}$ is also considered to be the all-transcending human in terms of erudition as he passed beyond human limits. To attain desired enlightenment is the objective of life and to then be released from the cycle of rebirth and death and this then leads to Nirvana. There are various sources of Holy Scripture. The Tripitaka (Sanskrit: त्रिपिटक), also called Tipițaka (Pali), means 'Three Baskets' is the Buddhist canon which is composed of three key sections termed the Discourses, the Discipline and the Commentaries (Kalupahana, 1994). There are also 2,000 sutras, which are sacred teachings that are embraced principally by Mahayana Buddhists as well as the Tibetan 'Book of the Dead' which pronounces on the stages of death. The Tripitaka is considered to be a record of the words of Buddha. The Pali canon was written in the first century CE. The Dhammapada means 'the path or verses of truth' and is the best known of all the Buddhist scriptures but there are additionally some early scriptures, inter-alia the Gandhara texts which all help one attain a state of inner peace and wisdom. The symbolism in Buddhism comprises of a conch, an endless knot, a fish, a lotus, a parasol, vase, dharmachakra (the Wheel of Dharma), and a victory banner.

\section{The basics - Orthodox Christianity}

Christianity is a monotheistic religion and accepts as a fact that Christ is the Son of God and is the founder of the Church which is thus based on the Life and Teachings of Jesus Christ the incarnate Logos who was sacrificed at Golgotha for the atonement of the human race. Fundamentally the Orthodox Church shares much with the other Christian Church denominations in the confidence that God revealed himself via Jesus Christ, and a belief in the incarnation of Christ, His crucifixion and glorious resurrection. The Orthodox Church does differ in the way of life and worship of Protestant churches, but shares many similarities with the Anglican and Roman Catholic Church. In each of these Jesus is the 'God-man' (Nicolaides, 2019).

Originally the Eastern and Western Christian Churches shared the same faith, however the two sides began to separate after the seventh Ecumenical Council in $787 \mathrm{CE}$. and this is considered to have in due course divided the Church over the dispute with Rome in the socalled Great Schism in 1054 CE. The precursor was the papal claim to supreme authority and infallibility and the doctrine of the Holy Spirit. The split became conclusive with the failure of the Council of Florence in the 15th century CE. Ultimately, the Western Church progressively identified itself with the " Roman Catholic" label, and Western Europe slowly associated the "Orthodox" label with the Eastern Church.

Man in the Holy Bible is a being in relation to God the Pantocrator Creator. The fall of humanity is a tragedy of a sorely broken relationship between Creator and his creatures. The split or separation still resounds through all of human existence. Humanity is guilty and requires redemption. Christians generally have faith in the idea that Jesus was the Messiah promised in the Old Testament who would come to redeem his people. The Church is an inimitable entity encompassing the Revealed Truths of the Christian religion and it exemplifies the Christian faith, projects the notion of Christian hope, and gives life to Christian agape (love). God the Father, out of his love and kindness, sent Christ to save humanity and to remain forever in the Ecclesia (Church) which He founded. Christians are required to understand the content of the sacred Sources in order to reinforce their faith in God and to receive Jesus Christ as the only Saviour by Whom and in Whom humanity's personal salvation is fashioned (Zizioulas, 2006). Man has inherited "original sin" from Adam. Humanity is thus fallen and is 
characteristically evil and in need of forgiveness of sin. By knowing right and wrong Christians select their actions. All humans are a fallen, fragmented race in dire need of salvation and restoration by an omnipotent, omnipresent and omniscient loving and forgiving God.

The practices on the Church developed over many ecumenical councils and synods (Nicolaides, 2014), include fastidious prayer, the observance of holy sacraments, worship in church, reading of the Holy Bible, partaking of the Holy Eucharist (Holy communion), acts of charity (Harakas, 1999). The Church's ministry (diakonia) contributes to human salvation and it is the complete strength of faithful and devout believers who constitute the "royal priesthood" by their sanctification and devotion to God. There is belief in a Trinitarian godhead comprising the Father, Son, and Holy Spirit (The Holy Trinity). The second person of the Holy Trinity, Jesus Christ the Logos, and the Third Person, the Holy Spirit, are of the same essence, Homoousios, of the Father. The nature and characteristics of the Persons of the Holy Trinity are exposed through Jesus Christ (Harakas, 1992). The truth can be grasped only through strong faith, as it is generally above and beyond human understanding. Jesus Christ was sent for this divine mission "when the fullness of time was come" (Galatians 4:4), when humanity was prepared to accept Him as his Saviour. Christ is a Theathropos (God-man) with two perfect natures, the divine and human, as God-man. The Orthodox Church considers the chief happening in the life of Christ to be His Glorious Resurrection since He presented Himself, as "the resurrection and the life" (John 11:25). Without this belief in the Resurrection, the preaching and the faith of the Church is ineffective, as Apostle Paul declares (1 Corinthians 15:14). The Church believes that Christ will return "... again with glory to judge" the world and everyone on earth, to "render to every man according to his works" (Romans 2:6) of faith in Christ and His Gospel, his love expressed in good works, and in helping others. Ethical practices are required and are non-negotiable (Cotsonis, 1964).

Jesus Christ commends His own Being to the Church, passing down divine Revelation in an oral form, and later this was all recorded in written form. This constitutes what is termed as Holy Tradition at large (Nicolaides, 2010). The content of the Scriptures was written by elected and stirred individuals, prophets and disciples, under the direction of the Paraclete (Holy Spirit). The Holy Spirit is the ultimate author and protector under whose direction and defence the Scriptures become the inspired and infallible basis of faith and salvation. Pascha (Easter) is the most evocative and holy season of the Orthodox Church calendar. It principally commemorates the resurrection of Jesus Christ with a succession of celebrations or 'movable' feasts. In Eastern Orthodox Christianity, the spiritual preparations begin with Great Lent, 40 days of contemplation and fasting, which starts on Clean Monday and finishes on Lazarus Saturday.

The faithful as well as all saints and sinners, gather together under the Church's shelter to accomplish repentance and forgiveness and strive for inheritance of God's Heavenly Kingdom as opposed to Hell. The Church is an infirmary for ill souls and its teaching and sanctification of the faithful assist in their redemption. Jesus Christ is "the Lord God, who is, and who was, and who is to come, the Almighty" (Revelation 1:8). He is "Jesus Christ, Who is the faithful witness, and the first-begotten of the dead, and the prince of the kings of the earth that loved us, and washed us from our sins in his own blood" (Revelation 1:5). John chronicled, "This is life eternal, that they might know thee, the only true God" (John 17:3). The Orthodox Christian must be led to believe not simply in a God, but explicitly to believe in the "True God" as revealed in the Scriptures and in the Person and teachings of Jesus Christ (Florovsky, 1963). "God as Creator created the heavens and the earth, the whole universe. He created angels as "ministering spirits sent forth to minister for them who shall be heirs of salvation" (Hebrews $1: 7,14)$. Almighty God created man and provides for all his needs of life, giving sanctification as well as "newness of life" out of love" (Mastrantonis, 2015). The Scriptures declare "to us there is but one God, the Father" (1 Corinthians 8:6); "in him (the Son) dwelleth all the fullness 
of the Godhead bodily" (Colossians 2:9; cf. Matthew 26:63); and, relating to the Holy Spirit, "thou hast not lied unto men, but unto God" (Acts 5:4).

The Church formulates, describes, and pronounces some Revealed truths and the Holy Fathers of the Church have assembled in synods to deliberate upon disputed arguments and to decree and interpret the correct meaning of those truths (Mantzarides, 1995). The first seven ecumenical councils were between the years of 325 and $787 \mathrm{CE}$. with the purpose of creating believed canons of faith. When synods of the Fathers met and when they now meet, their decisions are not considered to be permanent until they are acknowledged by the "Conscience of the Church," the whole body of the faithful, clergy and laity, who are required to give their agreement. The teachings and the practices of the Orthodox Church emanate from Holy Scriptures and Sacred Apostolic Tradition, which have been handed down to the Church of Christ in the Revelation of God through the generations (Papademetriou, 2005). The sacred ceremony of Baptism with that of Chrismation and the ceremony of the Holy Eucharist with that of Confession are the sacred Mysteria (sacraments) which all Christians ought to have as an active communicant of divine Grace. The other sacraments namely, ordination, marriage, and unction are not obligatory (Mastrantonis, 2015). Most Orthodox Churches have both ordained married priests and celibate monastics, consequently celibacy is a choice. All of the Patriarchs, Archbishops and Bishops are typically taken from the ranks of ordained monks.

The Eastern Orthodox Church is organized into self-governing (autocephalous) churches, many of which carry the title of patriarchate. Traditionally, the foremost authority in Orthodox Christianity is the Ecumenical Patriarchate of Constantinople (Istanbul), currently presided over by His Holiness Bartholomew I. He does not exercise the power enjoyed by the Pope in the Roman Catholic Church, but is considered by his followers to be "primus inter pares" (first among equals). The Church venerates the 'God-Bearer' Theotokos the Virgin Mary, as "holder of Him Who is illimitable...and the infinite Creator" and the dominion of God is entrenched in the freedom of man's nature and destiny in understanding and obedience inside the Church which is guided by the Holy Spirit, Who remains in it until the end of the ages (Mastrantonis, 2015). Monasticism (from Greek: $\mu$ ovaxós, a solitary person) is practiced in Orthodoxy and is the extraction from the world by people in order to dedicate themselves intensely to the life of the Gospel, in search of union with Jesus Christ. The emphasis of monasticism is on Theosis, ( $\theta \varepsilon \dot{c} \omega \sigma / \zeta$ becoming 'God-like') the process of perfection to which all believers are called. A monk or nun take vows to follow not only the commandments of the Church, but also take vows of poverty, chastity, constancy, and obedience. Orthodox monks practice hesychasm, the spiritual struggle of purification ( $\left.k \alpha \theta^{\theta} \alpha \rho \sigma / \zeta\right)$, illumination $(\theta \varepsilon \omega \rho i \alpha)$ and divinization $(\theta \varepsilon \dot{\varepsilon} \omega \sigma / \zeta)$ in prayer, the sacraments and obedience.

\section{Similarities Between Buddhism and Christianity}

In both religions a master founded them and taught people using parables. Both emphasize ethical life styles, care and compassion for others and all beings and the need of transcending the limited human condition. There are many similarities between Jesus and Buddha for example, both were conceived in a miraculous manner and were child prodigies. Both fasted for long periods and were tempted by the devil. Both started there ministers at about age 30 and had disciples travelling with them who later spread the faith. Both accomplished miracles, and rejected materialism. Buddha and Jesus Christ had common beginnings and each was born into a very traditional religious environment in which strict social classes existed. Both advanced new ways of thinking and promoted ways of overcoming rigid social systems.

There are also a number of analogous sayings in the teaching wisdoms of Jesus and Buddha but only few are mentioned here. The similar sayings include issues relating to salvation, sin, temptation, eschatology, compassion and so forth (Pettinger, 2013). Both Jesus and Buddha 
urged people to rise above the physical world and told their followers to seek spiritual principles and to develop deep spiritual consciousness. Both Jesus and Buddha promoted mindfulness practices encouraged contemplative action although the first was through prayer and the second through meditation.

While Jesus urges us to "Do to others as you would have them do to you" (Luke 6.31), Buddha advises "Consider others as yourself" (Dhammapada 10.1). Jesus states "Blessed are you who are poor, for yours is the kingdom of God" (Luke 6.20), while Buddha urges "Let us live most happily, possessing nothing; let us feed on joy, like radiant gods" (Dhammapada 15.4). Buddha argues "If anyone should give you a blow with his hand, with a stick, or with a knife, you should abandon any desires and utter no evil words" (Majjhima Nikaya 21.6) and Jesus maintains "If anyone strikes you on the cheek, offer the other also" (Luke 6.29). Both were tempted by evil forces. In Jesus case "When the devil had finished every test, he departed from him until an opportune time" (Luke 4.13), while for Buddha "During the six years that the Bodhisattva practiced austerities, the demon followed behind him step by step, seeking an opportunity to harm him. But he found no opportunity whatsoever and went away discouraged and discontent" (Lalitavistara Sutra 18). Buddha informs us that "The avaricious do not go to heaven, the foolish to not extol charity. The wise one, however, rejoicing in charity, becomes thereby happy in the beyond" (Dhammapada 13.11) and Jesus asserts "If you wish to be perfect, go, sell your possessions, and give the money to the poor, and you will have treasure in heaven" (Matthew 19.21).

Christ taught us to love those that hate us while Buddha taught that abhorrence cannot be overcome by more abhorrence. In the religious and social practices realms both were against rituals with no spirituality in mind and both sought spiritual enlightenment and perfection for humanity. Christ disparaged the money lenders in the temple who had made His Father's house a 'den of thieves' (Matthew 21:12-13) and he was not afraid to challenge the hypocritical religious leadership. In similar vein, Buddha also complained about the rigid caste system and duplicity of the Brahmins and castigated them. Shared values exist in the faiths for example,

The Five Precepts of Buddhism including refraining from killing, dishonesty, theft, sexual immorality, and unethical living align well with Christian teachings as do their teachings on observing charity for the less fortunate in society. Jesus and Buddha both accepted that what they taught applied to all people not just certain elements or groups in society. Both called out those who said they were spiritual and care for others but whose behaviour confirmed that they were self-centred hypocrites who appeared to be righteous on the 'outside'.

An additional parallel between these two religions' includes the realm after death. People in each religion can either transcend to a more "evil" place, such as Hell in Christianity or "the hells" after re-embodiment in Buddhism. One's behaviour ultimately determines where one goes.

\section{Some differences between Buddhism and Christianity}

There are numerous differences between Christianity and Buddhism. The Orthodox Nicene Creed, states that "We believe in one God, the Father Almighty, Maker of heaven and earth, of all that is seen and unseen" whereas Buddhism does not accept a theistic creation at all.

There are some disparities in Buddhism where some believe in a very detached eternal Buddha or creative force, but overall Buddhism understands the universe as being eternal and without any starting point or conception (Guang Xing, 2005). Eschatologically speaking, Buddhism raises the issue of specific cycles of life, Buddhist eschatology does not relate to any "final things", or even suggest that the world will end one at some point since there is 
never-ending cycle of birth and death which has no beginning. Christianity stresses the notion of the end times and the Last Judgement when the world will reach its conclusion as Christ returns to raise the living and the dead to judge them for acceptance into the Heavenly Kingdom. Everything started with the moment of creation, was moved and transformed by the Incarnation of Christ and will reach the final stage at the moment of Judgment.

\section{A. Morality and Ethics}

In the Christian faith, the adherents believe in God, who has created everything including laws that people need to adhere to. When one strays from the laws of God, one is sinning and thus misses the opportunity for entering into God's Heavenly Kingdom in the afterlife. In Buddhism however, according to the Dharma, the wisdoms of Buddha are considered to be the greatest form of godly understanding. Thus in Buddhism one is virtuous when they become enlightened and remove all suffering in their daily existence. One has no soul and attaining nirvana is the desired objective of life.

When it comes to notions of good versus evil, and moral principle in general, Christians are to uphold the Ten commandments passed down to Moses as well the 'new' commandment provided by Jesus to love one another as he has loved us. Humanity is required to adhere to the moral standards that God has stated are needed and He will reward us in turn. God's law should not be transgressed by people committing evil acts Paul teaches us in Romans 3:20: "Therefore no one will be declared righteous in His sight by observing the law; rather, through the law we become conscious of sin." When people act unethically and immorally and sin and do not confess their sins, they are hell-bound. Salvation is only possible through the observance of the word of God.

Buddhism's teaching on good and evil on the other hand, concentrates on teaching its adherents how to recognize "the truth" of life through becoming enlightened so they can beat dukkha, or pain and suffering. and attain spiritual heights. Buddha uncovered and preached Four Noble Truths which fundamentally deliberate on how a state of being comes with displeasure and pain due to one having egotistical desires and cravings and he explained how dukkha cannot be eliminated without getting rid of unnecessary desires and cravings. (Payutto, 2017). The transient character of all phenomena, including the self, creates a kind of distrust attitude for the external world, all phenomena being connected to desire and extinguishing all kinds of desires can be achieved only through nirvana (Zaehner, 1957). To achieve nirvana requires right action and no egotistical approach to life (Crosby, 2006). One needs to consider others, not be greedy, be zealous and think clearly after careful meditation. In the Dhammapada, V. 183, we read that one needs "The avoidance of evil, the undertaking of good, the cleansing of one's mind; this is the teaching of the awakened ones" (Partridge, 2005). Buddhists do not have faith in a soul and therefore have no system for one to be penalized for the wrongdoings the perpetuate. A Buddhist needs to align with doing "good" and kusala and the Four Noble Truths or attaining nirvana becomes remote.

Buddha's teachings disclose what moral and ethical approach is beneficial and "skillful" in helping one to arrive at enlightenment. Consequently, Buddha's Eightfold Path assists as a guide on moral principles for Buddhist adherents. Buddhists use the terms kusala (skilled) or akusala (unskilled) as opposed to "good and evil" to designate what is morally and ethically correct in terms of the law of karma which accepts it as true that when a person does good in life's situations and lives virtuously, they will obtain good and live in a higher state of consciousness. People who suffer do so due to their own wrongdoing and the evil acts which they perpetrate (Strong, 2001; 2015). 
Buddhists are not hugely absorbed in the renewal of an evil world, and spend much time and energy on refining their inner lives, professing a cyclical view of time. "The Buddhist emphasis on the negative elements of life and the concept of karma lead to individualism and rejection of the outer world. Community is based on common discipline. History and mission in this world are of little consequence" (Bloom, 1956). The Orthodox Christian and general Christian appeal to relationship building and decision making gives life a sense of mission and community is based on common decision and mission, viewing time as a linear process which culminates in the eschaton. Thus the metaphysical and religious orientations of the two religions differentiate them considerably. Buddhism and Christianity have distinct ethical laws. Buddhist ethical practices are to a large extent based on the 'The Four Noble Truths'. Moral virtue is considered to be basic in creating all positive things in life. Cause and effect (karma) are critical to consider as is the notion of reincarnation and the definitive objective of life is to break free from the wheel of reincarnation and attain nirvana based on attaining sublime truth (UKEssays.2018). One is required to be wise and have a right view of things (panna) based on meditation (samadhi) and virtue (sila). Consequently there should be no deceitful living but rather a striving for righteousness (Gwynne, 2011). Buddhist morality is then based upon the extent to which judgements are made and actions taken, will then either advance or obstruct one's pursuit of deliverance. No transcendent god supplies commands to be obeyed. One then needs to be skilful to determine the difference between what is ethically correct or wrong.

Buddhist ethical teaching is the Pancasila comprises of five principles including to refrain from destroying living creatures; to refrain from taking that which is not given; to refrain from sexual misconduct; to refrain from false speech and to refrain from intoxicants which lead to carelessness (Gwynne, 2011). The learning in life is ongoing. Buddha explains the importance of learning in human life. "This man of little learning grows old like an ox; only his flesh grows but not his wisdom" (Dhammapada 152). Morality and ethics are highly stressed and moral implementation is the quintessence of human development which needs to endure throughout life (Edelglass, 2013). Buddha highlights moral application in the Samyutta Nikaya, Verse 2320: "Brahmin; I will not put the wood to light the fire on the altar. Only in self, my fire ignites. With this unbroken fire burning, and with a self that is always controlled, I live a precious and noble life."

The dynamic action of Pancasila is termed pancadhama. These are principles which offer provide a basic moral code and which need to be recited on a daily basis by the faithful as well as monks at vital times including birth, marriage and death.

\section{Pancadhama comprises of:}

a. Metta Karuna, having a sincere love and compassion for all living beings and creatures. This idea aligns with the wheel of reincarnation since in the Buddhist worldview one may be reincarnated as other life forms (Gwynne, 2017, Harvey, 2000).

b. Samma Ajiva, earning 'right' livelihood, and conducting business honourably and with virtue. This inspires adherents to be generous in life, not only in monetary terms but in using one's time and energy to help others.

c. Santuthi, stresses avoiding immoral acts and refraining from sexual misconduct. Celibacy is then considered to be a higher form of spiritual existence.

d. Sacca, being honest at all times and in all situations. Individual enlightenment cannot be attained without honesty (Gwynne, 2017).

e. Satisampajana, careful thought as to what is imbibed and ingested by people. One should avoid harmful foods and drinks. Clarity of mind is an critical quality for Buddhists (Bodhi, 2005). 
An ethical and moral life is obtained based on knowledge of the faith, and belief in religious principles. "The person who can control his senses is like a coach who can control his horse, who has been able to eliminate his arrogance and only tenaciously can cleanse his mind from stains. The person like this is loved by the gods (Dhammapada 94)".

In Christianity Jesus teaches: "29 And Jesus answered him, The first of all the commandments is, Hear, O Israel; The Lord our God is one Lord: 30 And thou shalt love the Lord thy God with all thy heart, and with all thy soul, and with all thy mind, and with all thy strength: this is the first commandment. 31 And the second is like, namely this, Thou shalt love thy neighbour as thyself. There is none other commandment greater than these" (Mark 12:29-31, KJV).

The Orthodox Christian has the prospect to live out God's divine plan and enjoy eternal communion with the Creator. Saint Paul teaches in Romans 2:14-16 (KJV): "14 For when the Gentiles, which have not the law, do by nature the things contained in the law, these, having not the law, are a law unto themselves: 15 Which shew the work of the law written in their hearts, their conscience also bearing witness, and their thoughts the mean while accusing or else excusing one another;) 16 In the day when God shall judge the secrets of men by Jesus Christ according to my gospel."

Christian ethical teachings based mainly on the utterances of Jesus Christ are an inclusive guide to moral living and practices to be followed and are thus highly Christocentric since Jesus as the God-man is 'without spot of blemish' and he is perfect and the role-model for Christian living. The Saints are also a spiritual 'doorway' through which humanity is directed towards God and ultimately His Heavenly Kingdom. People in all faiths generally adhere to a "natural law", comprising an inner sense of morality exemplified in the "Golden Rule" of ethics which to treat one's neighbour as one would like to be treated by him or her.

Christianity and Buddhism both have concerns about how individual's morality will impact upon their spiritual standing. Orthodox Christian ethics are based on set of guidelines based on Holy Scripture, Holy Traditions and the teachings of the Early Church Fathers and focus on huma atonement and salvation. Buddhist ethics serve as a guide for life towards nirvana.

\section{B. Peace}

Orthodox Christians are called to encourage global peace and to desist from the use of violence in any form and this aligns with the African notion of Ubuntu in Africa as well as many other global philosophies (Nicolaides, 2005). Jesus put it succinctly when he said: "You shall love the Lord your God with all your heart, and with all your soul, and with all your mind, and You shall love your neighbour as yourself" (Matthew 22:36-40). When peace is broken it is due to sinful human nature and it separates humanity from the Creator. The Greek Eirini (peace) means reuniting what has been disturbed. The peace that God confers upon the world is given not only to humanity but also to the entire created world. Nature and history are, for the Christian faith, ontological realities bearing the marks of sinfulness as separation, division, opposition, ethical and natural evil, as well as the realm, the space, in which the drama of the salvation of the whole world is unfolding through the dynamic presence of God's Spirit in them (Clapsis, 2011). Christians can participate in the progression towards salvation as they embrace, in love, all human beings. In what is a highly complex and violent world, Orthodox Christian churches recognize, along with other denominations and religions, that working for peace is a core expression of human responsibility for the entire world. Human accountability is based on the basic inherent goodness of all human beings and for all that God has created to be carefully protected. Seeking peace offers opportunities for believers to link theology with ethical witness and "...faith with social transformation. The dynamic nature of peace as gift 
and vocation does not allow its identification with stagnation, passivity and the acceptance of injustice" (Clapsis, 2011).

The sacrifice of Christ at Golgotha must be the source of the meaning of faith. Anything which fails to conform to agape love is non-Orthodox. The Church however is to a large extent silent on the "renunciation of the violence, war, and terrorism as destructive of human lives, unjust and oppressive becomes a credible expression of the Church's faith only when it is complemented with ethical practices that point to their prevention. The peaceable witness of the Church in situations of conflict and war cannot be limited only to its ethical judgment about the legitimacy and rules of conduct of war or even its unconditional renunciation...A remedy to this limitation is for the churches to develop just peace-making practices that move their ethical discourse from theories that justify or regulate the use of violence to preventive actions that contribute to the building up of a culture of peace" (Stassen, 2008).

Orthodox Churches need to counterpart their ethical judgments with peace making and peacebuilding actions. Prior to the Glorious Ascension of Jesus into heaven, He gives his peace to his disciples as a precious gift. It is valuable because it will make them robust and give them valour to go on for their mission and overcome dread. "Peace I leave with you; my peace I give to you. I do not give to you as the world gives. Do not let your hearts be troubled, and do not let them be afraid" (John 14: 27). The Church should make greater efforts to support efforts whose intention it is to identify more effective ways of resolving disputes without resorting to violence. The Church should strive to enable people caught up in violence and war to find God's peace and justice through reconciliation, reparation and forgiveness (Cortright, 2008). There must be a common message of peace, that all religious faiths espouse. Only in this way can others be viewed as a 'brother and sister. Orthodoxy teaches that violence and war begins chiefly in people's hearts where arrogance, loathing and a yearning for revenge all take shape. What is then needed is a more enlightened human consciousness where love abides as a core facet.

Thus, peace and peace-making are requisite aspects of faith. The Holy Eucharist allows adherents to distinguish right from wrong and experience the fullness of the Orthodox Christian faith. God Himself is Peace (Judges. 6:24) and peace is His gift to humanity and is a sign of communion with God, who gives peace to those who serve him (Psalms. 85: 8-13). Peace is virtually tantamount with salvation (Romans 16.20; 1 Thessalonians 5:23).

Peace is communion with God and Jesus Christ is our peace, since He is the bond of communion (Ephesians 2.14-17): "We live in peace with God through our Lord Jesus Christ" (Romans 5.1) The Orthodox Church has rather a dynamic obligation to the praxis of peace. The Church invites believers to strive for Theosis and become Christlike as fully as they can. and become the instruments for God's peace in the world (Clapsis, 2011). St. Nicholas Cabasilas states: "Christians, as disciples of Christ who made all things for peace, are to be

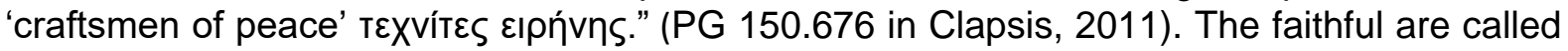
to a continuous spiritual struggle that leads, by the grace of the Holy Spirit, towards greater justice and peace. However prayer and repentance and alignment with the Gospel of love are needed as humanity seek atonement with God.

Buddhism provides rich resources for peace-making and non-violence (Reed, 2004) and one of the fundamental teachings is non-violence (Ahimsa) which also aligns with the notion of love. Peace-making is one way a believer can arrive at nirvana. The key is to do no harm to others (Der-LanYeh, 2006). Buddhism is renowned as a religion of peace and non-violence. Within its teachings it is understood that nothing can exist on its own and everything is dependent on other things as there is a ripple effect in operation. This confirms that all entities and indeed all singularities are related directly and indirectly to one another in the cosmic reality. When one thing changes it impacts on a range of other things (Der-LanYeh, 
2006). People have a huge responsibility for the actions they perform and the desired course of action that should be followed must of necessity involve benevolence and beneficence.

Buddha referred to four basic mental faculties (Brahmaviharas), or divine stances, leading to "immeasurable deliverance of mind". These include loving-kindness (metta), compassion (karuna), sympathetic joy (mudita), and equanimity (upekkha). Buddha taught that four mental faculties, along with the with the Four Noble Truths, are to be cultivated by all bhikkhus all Buddhists through reflection on the sentient beings of infinite number who are on their path to enlightenment to become a buddha (Taisho 1:26 in Der-LanYeh, 2006). Through deep introspection one can arrive at a point where moderation exists in which a Buddhist can live in harmony with everything (sentient or non-sentient) in the Cosmos (Chappell, 2003).

The assessment of peace as a collective creation is in synergy with the Buddhist worldview based on the belief of dependent origination which highlights the mutual influence of all the elements involved in a situation. Where there is level-headedness, or peace of mind, one is able to extricate oneself from the cycle of desire that produces dukkha. Thus by achieving a mental state of enlightenment, one can disengage from all the passions, needs and wants of life, and free oneself and realize a state of transcendent bliss and total well-being in which peace prevails. Real peace originates from non-violence which is a rational and massive force. The practice of non-violence is life-affirming which underwrites human unity, advancement and ultimately peace. Non-violence imparts to one the idea of living in harmony with others and with oneself (Jayatilleke, 1969; Galtung, 1993). Nirvana is the place of perfect peace and happiness, though in a kind of impersonal void, since the absence of a personal god to be in communion with lacks in Buddhism. The idea or notion of nirvana as a way of liberation from suffering is intimately connected to the notion of anatta (non-self), which states that everything is changing including the self, which is non-permanent, actually Buddhism denying the existence of a soul or personality in human being (Stcherbatsky, 1923). Humanism was essential Buddha's teachings which crossed all racial and national barriers. "He sought the development of a new kind of free man, intent on working out his own future, with reliance on one's own self, attadipa “

In India, Buddha's policy of peace, self-sacrifice, kindness and charity not only
influenced people in general but also rulers who made it the basis of
their state policy. It moulded the lives of many saints in medieval India while
in modern period, too, leaders like Gandhi and Nehru were undoubtedly
guided by Buddha's teachings. The declared foreign policy of India was based
on Panchashila, in itself a Buddhist term which allows for the possibility of
peaceful co-existence between people of different ideologies. (Saksana, n.d)

The practice of non-violence (ahimsa) is highly life-affirming which underwrites the notion of human unity, development and peace. Non-violence teaches people to live in harmony with others and with themselves but necessitates strong self-control of the emotions (Walpola. 1974). Buddha instructed his followers to seek a deeper sense of service and understanding with love and compassion for all based on a higher morality. Ethical conduct and integrity are central to Buddhism along with avoiding harm and procuring happiness. Anything less would lead one to a life of misery and conflict. One thus needs a stable mind in the cosmic reality in which harmony prevails. The Buddhist ideal is for a life of creative altruism which leads to total harmony and it is based on the Four Truths (Gethin,1998a). Discord, strife and wars are the result of ignorance and these destroy peace. This is why people need to selfreflect on a regular basis and meditate in Buddhism (Sivaraksa, 1992). These actions will likely rid people of negative and adversarial thoughts. 
The only way a permanent peace can be established is by cultivating an enlightened mindset promoting peace (Shih Sheng-yen, 1999). The correct values of pacifism, empathy and altruism promoted by Buddhism seek to inspire all people who seek a harmonious life. peace. Buddha's teaching of incapacitating evil aided humanity in attaining a measure of peace. It had a huge impact on the general and social existence of the society and thus supported social accord. It invigorated the spirit of social solidarity by seeking to put an end to social conflicts (Walpola, 1974; Sivaraksa, 1999).

\section{Conclusion}

In conclusion, through this brief investigation of the two contrasting religions, Orthodox Christianity and Buddhism, a large range of similarities manifest, contrary to what one could expect to discover. The teachings, laws, ethical stances and a variety of other aspects appear to be in concord. Both Jesus Christ and Buddha, presented illustrations of morality which are analogous in nature especially on the notion of love for others. Both Buddhism and Christianity have substantial and severe impediments and castigations for people who do not adhere to the ethical rules and guidelines of their faith. Both faiths have a love for humanity. By juxtaposing Christianity and Buddhism, one finds that both faiths offer their followers a succinct list of moral directives namely the Five Precepts for Buddhism and the Ten Commandments and Christ's 'new commandment' of agape, for Christianity.

A key difference between the two is that some of the Ten Commandments deal with how people ought to relate to God, and are God-given, whereas in Buddhism the Precepts include no comparable advices and are guiding principle for those on a quest for enlightenment. There is however some parallel in that there are four orders are very similar in both religions namely, no killing, no stealing, no deceitfulness, and no adultery or sexual misconduct. Buddhism teaches that there is an established route in order to reach the eventual end goal which is nirvana, while in Orthodox Christianity one needs to accept Jesus as the Messiah of the world and adhere to Holy Scripture, Holy Traditions and the writings of the Early Church Fathers to obtain atonement and thus have hope for God's heavenly Kingdom. It is evident that societal moral standards in each faith are more interrelated than one would imagine and both seek peace and harmony in life. Buddhism gives its key focus to the way of mystical pursuit, linked to reasoned inquiry and right action. Enlightenment is possible through meditation, learning, and a strict moral discipline (Cannon, (2020).

Both faiths contain and propagate ethical conduct and have a desire to promote peace. Nonetheless, despite basic level similarities, Buddhism and Christianity have characteristic and important differences. For one, Christianity is monotheistic, while Buddhism's is essentially non-theistic and it rejects the concept of a creator God, which is a basic Christian teaching. In Buddhism, karma is important for reincarnation while for the Christian adherent, God's grace is of paramount importance. Buddhism seems to be more a religion of human condition, founded on the need to come out of the phenomenal drama of suffering, but rather in a more philosophical and psychological manner. Buddha died a peaceful death at an old age compared to Jesus who was offered 'as a willing lamb to the slaughter' for the atonement of the sins of all of humanity.

Buddhism affords high priority to a philosophical quest of the way of reasoned inquiry to enlightenment whereas Christianity accepts the conviction that God has decisively acted and has communicated His will in history and He reveals himself and His redemptive and atoning desire for a fallen humanity through prophets and ultimately through His only begotten Son, Jesus Christ. Ultimate reality is known and knowable in and through the redeeming Jesus Christ. 


\section{References}

Anderson, C. (1999). Pain and Its Ending: The Four Noble Truths in the Theravada Buddhist Canon, London: Routledge.

Bloom, A. (1956). A Basis for the Comparison of Religions: Christianity and Buddhism, Journal of Bible and Religion, Oct., 1956, 24(4).(Oct., 1956), pp. 269-274

Bodhi, Bhikku. (2005). In the Buddha's Words: An Anthology of Discourses from the Pali Canon, Simon and Schuster.

Burtt, E. A. (1955). The Teachings of the Compassionate Buddha, New York: Mentor Books.

Cannon, D. (2020, May 18). Comparing Buddhism and Christianity as Whole Traditions.

Available online at https://chem.libretexts.org/@go/page/37103

Chappell, D. W. (2003). "Buddhist Social Principles." In Kathleen H. Dockett, G. Rita DudleyGrant, and C. Peter Bankart, eds., Psychology and Buddhism: From Individual to Global Community (pp. 259-276). New York: Kluwer Academic/Plenum Publishers.

Clapsis, E. (2011). Peace and Peacemaking as an Interfaith and Ecumenical Vocation: An Orthodox View. Available online at https://www.goarch.org/-/peace-and-peacemaking-as-aninterfaith-and-ecumenical-vocation-an-orthodox-view

Corduan, W. (1998). Neighboring faiths: a Christian introduction to world religions. Downers Grove: InterVarsity Press

Cortright, D. (2008). Peace: A History of Movement and Ideas (Cambridge: Cambridge Uni-versity Press.

Cotsonis, J. (1964). "Fundamental Principles of Orthodox Morality", in AJ. Philippou (ed.), The Orthodox Ethos: Studies in Orthodoxy, Holywell Press, Oxford.

Crawford, R.G. (2002). What Is Religion? London: Routledge.

Crosby, K. (2006). "A Theravāda Code Of Conduct For Good Buddhists: The "Upāsakamanussavinaya" Journal Of The American Oriental Society, 126 (2), 177-187.

de Bary, W. (1969). The Buddhist Tradition in India, China and Japan (February 1972 ed.). xvii: Vintage Books. p. xvii.

Der-LanYeh, T. (2006). The Way to Peace: Buddhist Perspective, International Journal of Peace Studies, 11(1), Spring/Summer.

Durkheim, E. (1915). The Elementary Forms of the Religious Life. London: George Allen \& Unwin.

Edelglass, W. (2013). "Buddhist Ethics and Western Moral Philosophy" (PDF), in Emmanuel, Steven M. (ed.), A Companion to Buddhist Philosophy (1st ed.), Wiley-Blackwell.

Florovsky, G. (1963). 'Worship and everyday life: An Eastern Orthodox view', Studia Patristica, 2.

Fowler, M. (2005). Zen Buddhism: beliefs and practices, Sussex Academic Press.

Galtung, J. (1993). Buddhism: A Quest for Unity and Peace. Honolulu: Dae Won Sa Buddhist Temple.

Gethin, R. M. L. (1998). Foundations of Buddhism, Oxford University Press. 
Gethin, R. M. L. (1998a). "Four Truths: The Disease, the Cause, the Cure, the Medicine." The Foundations of Buddhism. New York: Oxford UP.

Gombrich, R. F. (1988). Theravada Buddhism: A Social History from Ancient Benares to Modern Colombo, Routledge and Kegan Paul.

Guang Xing. (2005). The Concept of the Buddha, Routledge Curzon: London.

Gwynne, P. (2017). World Religions in Practice: A Comparative Introduction, John Wiley \& Sons.

Harakas, S. S. (1992). Living the Faith: The Praxis of Eastern Orthodox Ethics. Minneapolis: Light \& Life.

Harakas, S. S. (1999). Wholeness of Faith and Life: Orthodox Christian Ethics, Part One: Patristic Ethics. Brookline, MA: Holy Cross Orthodox Press.

Harvey, P. (2000). An Introduction to Buddhist Ethics, Cambridge University Press.

Hirakawa, A. (1990). A History of Indian Buddhism: From Śākyamuni to Early Mahāyāna, University of Hawaii Press.

Hopfe, L. \& Woodward, M. (2005). Religions of the World, $9^{\text {th }}$ Ed. Upper Saddle River: Pearson Education.

International.Ia-croix.com (2014). Christianity and Buddhism: more similarities than differences. Available online at https://international.la-croix.com/news/religion/christianityand-buddhism-more-similarities-than-differences/227

James, W. (1902). The Varieties of Religious Experience. A Study in Human Nature. Longmans, Green, and Co.

Jayatilleke, K. N. (1969). Buddhism and Peace. Kandy, Ceylon: Buddhist Publication Society.

Kalupahana, D. J. (1994). A history of Buddhist philosophy, Delhi: Motilal Banarsidass.

Keown, D. \& Prebish, C. S. (2013). Encyclopedia of Buddhism, Routledge: New York.

Laumakis, S. (2008). An Introduction to Buddhist philosophy, Cambridge: New York: Cambridge University Press.

Mantzarides, G. (1995). Christianike Ethike [in Greek], 4th ed. Thessaloniki: Pournara.

Mastrantonis, G. (2015). The Fundamental Teachings of the Eastern Orthodox Church, GOARCH, Available online at https://www.goarch.org/-/the-fundamental-teachings-of-theeastern-orthodox-church

Merriam-Webster (2019). Religion - Definition of Religion by Merriam-Webster. Retrieved 12 February 2021.

Morreall, J. \& Sonn, T. (2013). "Myth 1: All Societies Have Religions". 50 Great Myths of Religion. Wiley-Blackwell.

Nakamura, H. (1964). Ways of Thinking of Eastern Peoples: India, China, Tibet, Japan, Honolulu, University of Hawaii Press.

Nicolaides, A. (2019). Jesus the Christ: Truly the Theanthropos, Pharos Journal of Theology, Vol. 100. 
Nicolaides, A. (2014). The Seventh Ecumenical Council and the veneration of icons in Orthodoxy, Acta Theologica, 34(2).

Nicolaides, A. (2010). The Laos tou Theou - an orthodox view of the 'people of God', HTS Teologiese Studies/Theological Studies, 66(1).

Nicolaides, A. (2005). 'Ubuntu promoting ethical business conducts in African Society. Orthodox and the great social and economic problems of Africa: The contribution of the great monotheistic to their solution', paper presented at the International Interparliamentary Assembly on Orthodoxy Conference, University of Johannesburg, 02 December.

Niebuhr, R. (1953). The Nature and Destiny of Man, New York: Chas. Scribner's Sons.

Nongbri, B. (2013). Before Religion: A History of a Modern Concept. Yale University Press.

Papademetriou, G.C. (2005). The People of God: An Orthodox perspective, Available online at http://www.goarch.org/ourfaith/ourfaith9285

Partridge, C. H. (2005). Introduction to World Religions. Minneapolis, MN: Fortress.

Payutto, Bhikkhu P. A. (2017). "Good and Evil in Buddhism." Available online at UrbanDharma.org. n.d.

Pettinger, T. (2013). Differences Between Buddhism and Christianity, Oxford, UK. Available online at www.biographyonline.net.

Pew Research Center, (2015). Chapter 1: Importance of Religion and Religious Beliefs. Available online at https://www.pewforum.org/2015/11/03/chapter-1-importance-of-religionand-religious-beliefs/

Pratt, J. B. (1951). The Pilgrimage of Buddhism. New York: Macmillan Co.

Rahula, W. (1974). What the Buddha Taught (2nd ed.). New York: Grove.

Reed, B.E. (2004). "Ethics”, Encyclopedia of Buddhism, Vol.1, edited by Robert E. Buswell, Jr., New York: Thomson Gale.

Rhys Davids, C.A.F. (1928). Dhammapada and Khuddakapatha. The Minor Anthologies of the Pali Canon, Sacred Books of the Buddhist Series.

Saksana, R. (n.d.). Buddhism and its message of peace. Available online at https://www.ayk.gov.tr/wp-content

Shih Sheng-yen. (1999). "A Pure Land on Earth." In David W. Chappell, ed., Buddhist Peacework: Creating Cultures of Peace. Boston, MA: Wisdom Publications.

Sivaraksa, S. (1999). "Buddhism and a Culture of Peace." In David W. Chappell, ed., Buddhist Peacework: Creating Cultures of Peace (pp. 39-46). Boston, MA: Wisdom Publications.

Sivaraksa, S.(1992). Seeds of Peace: A Buddhist Vision for Renewing Society. Berkeley, CA: Parallax Press.

Social Sci LibreTexts. (2021). 14.1 The Nature of Religion. Available online at https://socialsci.libretexts.org/Courses/Solano_Community_College/SOC_002\%3A_Social_I ssues_and_Problems/14\%3A_Religion/14.01\%3A_The_Nature_of_Religion Retrieved 08 February 2021. 
Stassen, G.H. (2008). (Ed.) Just Peacemaking: the new paradigm for the ethics of peace and war, Cleveland: The Pilgrim Press.

Stcherbatsky, T. (1923). The Central Conception of Buddhism and the Meaning of the Word "Dharma", London: Royal Asiatic Society.

Strong, J.S. (2001). The Buddha: A Beginner's Guide, Oneworld Publications.

Strong, J. (2015). Buddhisms: An Introduction. London: Oneworld Publications.

Thompson, E. (2020). Why I am Not a Buddhist. Yale University Press.

Tillich, P. (1957). Dynamics of faith. Harper Perennial.

Vergote, A. (1996). Religion, Belief and Unbelief. A Psychological Study, Leuven University Press.

Von Hinüber, O. (1997). A Handbook of Pali Literature (1st Indian ed.). New Delhi: Munishiram Manoharlal Publishers Pty., Ltd.

Yinger, J.M. (1970). The Scientific Study of Religion, London: Macmillan.

Zaehner, R. C. (1957). Mysticism Sacred and Profane: An Inquiry into some Varieties of Praeternatural Experience. Oxford: Clarendon Press.

Zizioulas, J. D. (2006). Communion and Otherness: Further Studies in Personhood and the Church, ed. Paul McPartlan. London: T. \& T. Clark. 